\title{
Infrastructure Development, Residential Growth and Impacts on Public Service Expenditure
}

\author{
Scott N. Lieske • Donald M. McLeod • \\ Roger H. Coupal
}

Received: 7 January 2014 / Accepted: 1 March 2015 /

Published online: 28 March 2015

C The Author(s) 2015. This article is published with open access at Springerlink.com

\begin{abstract}
This paper documents the use of geographic information science based planning support systems to evaluate the effects of infrastructure development on residential growth and resulting public service expenditure. The case example presented here investigates the impacts associated with a large water infrastructure development project. The effect of infrastructure on residential development is evaluated by comparing growth trends within areas of different levels of water supply and sewerage services. The effect of changing residential development patterns on public services expenditure is evaluated with a spatially explicit model linking urban form with revenues, expenditures and fiscally efficient areas of service provision for a delivery-based public service, police. Results confirm that the development of water infrastructure leads to residential growth and also indicate this growth in some locations leads to fiscally efficient provision of a public service. A primary recommendation from this research is that, in anticipation of growth, water planning should be comprehensive rather than single issue focused. Planning support systems are indicated to be useful tools supporting policy refinement for land-use and water planning.
\end{abstract}

Keywords Water $\cdot$ Land use · Urban form · Planning support systems

\footnotetext{
S. N. Lieske $(\bowtie)$

Sustainability Research Centre - ML28, University of the Sunshine Coast, Locked Bag 4, Maroochydore DC 4558 Queensland, Australia

e-mail: scottnlieske@gmail.com

D. M. McLeod $\cdot$ R. H. Coupal

Agricultural and Applied Economics, Department 3354, 1000 E. University Avenue, University of Wyoming, Laramie, WY 82071, USA

D. M. McLeod

e-mail: DMcLeod@uwyo.edu

R. H. Coupal

e-mail: coupal@uwyo.edu
} 


\section{Introduction and Context}

There are well-established links between water infrastructure development and residential growth as well as between increasing residential growth and increasing water demand (Hanak and Brown 2006). However, there remains a problematic disconnect between water planning and land-use planning in the western United States (Center for Natural Resources and Environmental Policy 2011; Cook et al. 2008; Hanak and Brown 2006). At the local government level there is well established land-use authority, but limited and sometimes unclear legal authority over water development (Cook et al. 2008). At the state level, there is often a focus on water development that may disregard both local and cumulative negative externalities. The impacts of the split between the responsibility for water and land-use offer an opportunity for research where better information can support improved planning and policy that may in turn help mitigate unintended consequences of development.

This research seeks to develop a clearer understanding of the relationships between infrastructure development and residential growth through investigation of the impacts of a state funded, regional water development project. The project at the center of this investigation is the Sheridan Area Water Supply (SAWS), located in Sheridan County, Wyoming. In the western United States, water availability and water quality protection have historically been administered separately (Center for Natural Resources and Environmental Policy 2011). In Wyoming, water planning and development of infrastructure for water supply fall under the jurisdiction of the Wyoming Water Development Commission (WWDC). Municipalities and counties are responsible for land-use planning but local governments have only limited control over water infrastructure development. For example, Wyoming municipalities may set water rates and purchase water from beyond their boundaries, but legal authorities for water management and infrastructure development are based on individual grants of power from the State (Cook et al. 2008). Water management and development is often under the purview of utilities that are distinct from city or county governments and often have jurisdictional and geographic boundaries that only partly overlap (Hanak and Brown 2006). Sewerage and waste water treatment is under the purview of municipalities. Beyond municipal sewerage service areas, waste water is largely treated by individual septic systems. In contrast, legal authority for local land-use planning is well defined with the main delegation of authority from the state to county and city governments (Hamerlinck et al. 2013).

SAWS originated in the mid-1980s with a study by the WWDC that addressed water supply and delivery issues in and around the City of Sheridan (Howard Needles Tammen and Bergendoff 1987). Included were issues concerning untreated water delivery in the Big Goose watershed as well as poor water quality and declining water quantity in the Little Goose watershed (Fig. 1). The WWDC became involved after the United States Environmental Protection Agency determined that the existing system violated the Safe Drinking Water Act. SAWS was proposed as an area wide water supply and treatment system to address these issues (Cook et al. 2008). SAWS infrastructure development was completed in multiple stages. A distribution pipeline from the City of Sheridan through Little Goose Valley was completed in 1992. A supply pipeline from the Big Horn Mountains through Big Goose Valley to the City of Sheridan was completed in 1996. As illustrated in Fig. 1, water pipelines extend throughout much of the SAWS project area boundary. Sewer lines are limited to within the urban service area surrounding the City of Sheridan. 


\section{Legend}

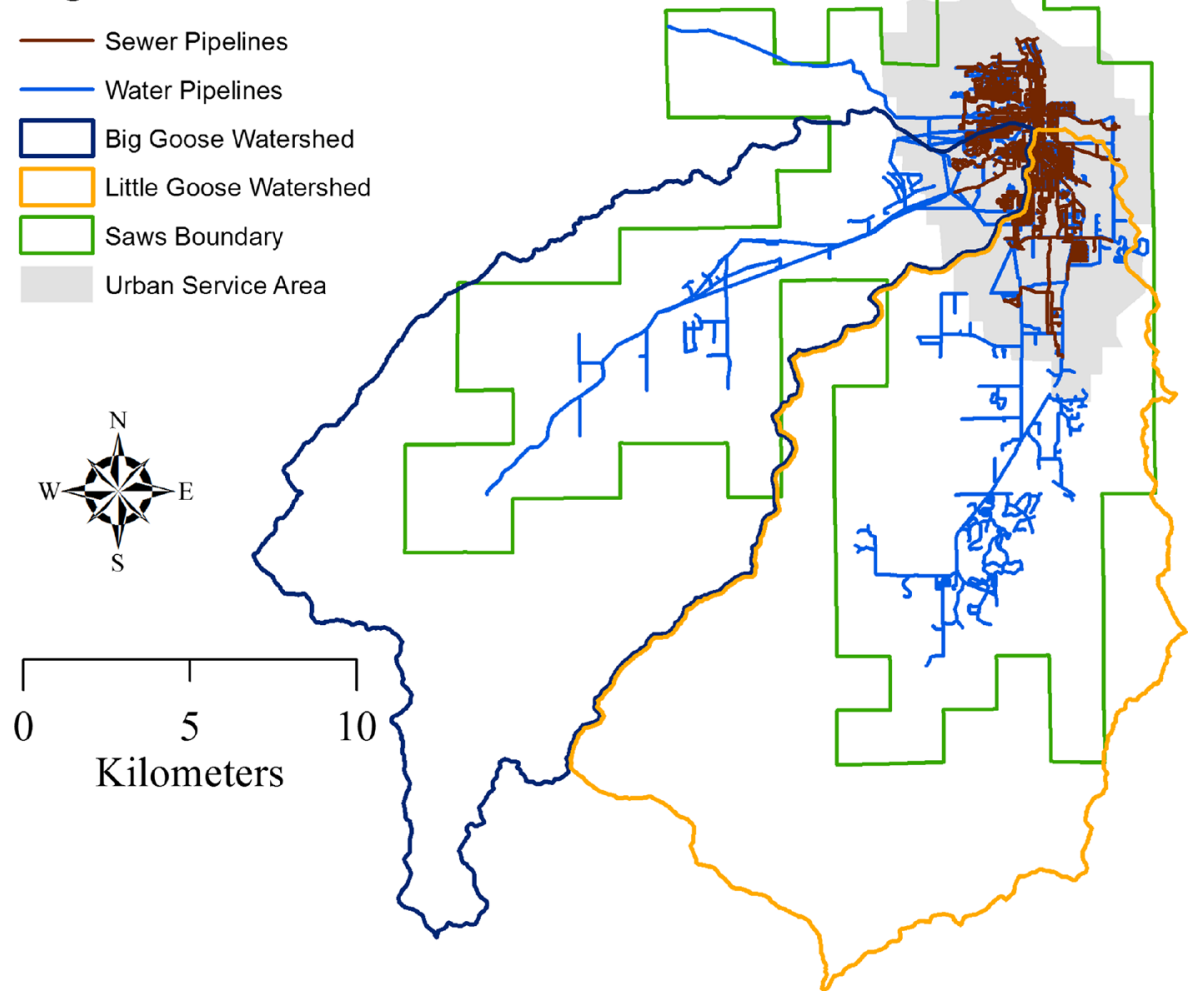

Fig. 1 SAWS project area water supply and sewerage service pipelines

Water development and land-use change in Sheridan County is framed by a number of planning documents that put forward both the community vision and policy recommendations. Vision 2020: Sheridan County Growth Management Plan (JGA Architects 2001) recommends that the City of Sheridan grow as an urban community rather than as a low-density rural area. Vision2020 recognizes increasing numbers of individual septic systems bring about concerns over potential health hazards (Cook et al. 2008). The Sheridan County Comprehensive Plan (Clarion et al. 2008) and the Sheridan Joint Planning Area Land Use Plan (Clarion 2009) articulate a public involvement-based preference for compact commercial and residential growth in urban areas in order to gain efficiencies in public service provision. The comprehensive plan designates an urban service area around the City of Sheridan where development may be efficiently provided with municipal water supply and sewerage services. The goal is to protect groundwater quality by limiting future development of residential septic systems (Clarion et al. 2008). The land-use plan states residential development not connected to the sewerage network could lead to further deterioration of surface and groundwater quality in the SAWS project area. Relevant policies articulated in the land-use plan are to limit septic systems in areas susceptible to groundwater contamination as well as discourage development and maintain very low residential density in riparian areas and areas of high groundwater vulnerability that lack sewerage service (Clarion 2009). 
SAWS successfully addressed the issues of untreated water and limited water supply. Yet, there are a number of areas where the impacts of the project are uncertain including the effect of water infrastructure development on land-use change and residential growth, impacts on public services expenditure as well as potential impacts on groundwater pollution. In a preliminary investigation, Cook et al. (2008) found a substantial increase in the growth of the number of residential parcels within the SAWS boundary in comparison with other areas of Sheridan County. They concluded that water supply infrastructure attracts residential development. Addressing the fiscal impacts of SAWS, Cook et al. (2008) developed a regression model that looked at general and delivery-based county expenditures for parcels inside and outside the SAWS project area. They found rural subdivisions in Sheridan County have a negative impact on county finances whether located within SAWS or not. They investigated and did not find potential economies of scale for public service provision based on density. Cook et al. (2008) also documented periodic potentially hazardous fecal coliform blooms in the SAWS project area. Residential development in SAWS relies on individual septic systems which are a suspected contributor to fecal coliform levels in Goose Creek. They note there are no perceptible trends in fecal coliform levels nor are monitoring efforts able to identify the source of the fecal coliform. They recommend a more comprehensive monitoring network capable of identifying pollutants by source (Cook et al. 2008). Water quality impacts from SAWS area residential development remain undetermined.

The above issues may be addressed through the use of geographic information science (GIS)-based planning support systems (PSS) to develop spatially explicit information in support of planning and policy. There are two somewhat conflicting threads in PSS research. Te Brömmelstroet (2013) notes implementation of PSS has been slow and unsuccessful for use in planning practice. At the same time, the utility of PSS is broadly supported (Lieske and Hamerlinck 2013). The apparent dichotomy between lack of success in planning practice and broad utility is explained, as least in part, because PSS continue to be valuable tools for research and analysis. Klosterman (1997) offered several recommendations for PSS components including specific software tools and support for continuous and interactive analysis and evaluation. NedovićBudić (2000) and more recently Geertman (2013) argue that analysis and problem solving are among the expected capabilities of PSS. Geertman et al. (2013) present a collection of papers highlighting the analytical capabilities of PSS. They also highlight the increasing use of PSS as research tools supporting spatial analysis and for the development of information and knowledge for planning and governance of sustainable urban systems (Geertman et al. 2013). The capabilities of PSS combined with emerging methods for spatially explicit evaluation of public services expenditure (Lieske et al. 2012, 2013) suggest new means of investigating the disconnects between infrastructure development, land-use planning, and land-use change.

\section{Methods and Data}

The methods and results of this investigation are divided into two main parts. The effect of infrastructure development on residential growth is evaluated by comparison of growth trends within regions defined by different levels of water supply and sewerage 
service in the study area. The effect of SAWS infrastructure development on public services expenditure is evaluated with an econometric model that evaluates the influence of urban form on expenditures. Our concept of urban form, the spatial distribution of fixed elements of the built environment, follows the definition presented by Anderson et al. (1996) modified slightly to focus attention on the relationship between the built environment and public service expenditure. Outputs of the econometric model are then used to develop spatially explicit revenue, expenditure and fiscal efficiency maps. The cornerstone of both the analysis of growth trends and the measure of urban form incorporated in the econometric model is a cadastrebased spatiotemporal land-use change model (following Lieske and Gribb 2012) based on a January 2013 State of Wyoming parcel dataset provided by the State of Wyoming Department of Enterprise Technology Services.

The effect of infrastructure development on residential growth is evaluated using PSS-derived metrics of the built environment. Data were developed using the quantitative capabilities of the CommunityViz ${ }^{\circledR}$ GIS-based PSS. The Scenario 360 module of CommunityViz enables formula-based spreadsheet-like calculations to be performed on geographic data. Formula-based map and data layer summary values are referred to as "indicators" (Walker and Daniels 2011, p. 33) and used to generate counts of residential parcels for each of the annual temporal snapshots from 1990 to 2011 in regions of different levels of water supply and sewerage service. These service regions are defined as follows: 1) the urban service area, including areas within municipal boundaries and/ or within the county urban services boundary, 2) the extra-municipal area (defined here as the area outside the urban service area, outside municipal areas and outside the SAWS project area), and the SAWS project area disaggregated into 3) the Big Goose and 4) the Little Goose watersheds.

Indicators capturing annual counts of residential parcels are used to calculate growth rates. Comparisons between regions may be made using growth rates rather than overall growth in order to overcome differences brought about by widely varying numbers of residential parcels in the service regions of interest. Growth rates are evaluated first with exploratory data analysis: (1) looking at overall and average annual growth rates from the time SAWS was completed, 1996 through 2011; and, (2) charting annual data in order to contrast year by year growth rates in the urban service area, SAWS project area, and Big Goose and Little Goose watersheds with growth in the extra-municipal area. Growth rates are then evaluated statistically using, (3) a linear regression test for trend and, (4) charts of differenced growth rates and trend lines that also disaggregate summary values to year by year changes and enable visualizing trends over time.

Hirsch (1970), Borcherding and Deacon (1972), Ladd (1992), Heikkila (2000) and Lieske et al. (2012) collectively provide a rationale for econometric modeling with a public service expenditure function that incorporates urban form. An econometric model of per service local government expenditure on a particular service may be written as:

$$
\widehat{E}=\beta_{a}+\beta_{b} M+\beta_{d} N_{e}+u_{1}
$$

where,

$\hat{E} \quad$ represents total estimated annual local government expenditures

$\mathrm{M}$ represents the spatial index that quantifies urban form 
$\mathrm{N}_{\mathrm{E}}$ represents vectors of service conditions (socio-economic and/or demographic characteristics) relevant to expenditure

$\beta \quad$ are estimated parameters on the relevant variables; and

$\mathrm{u}_{1}$ are residuals.

An econometric model of local government service production is presented as:

$$
S=\beta_{0}+\beta_{1} \widehat{E}+\beta_{2} N_{s}+u_{2}
$$

where,

$\mathrm{S}$ represents a measure of public service output

$\hat{E} \quad$ represents total estimated annual local government expenditures

$\mathrm{N}_{\mathrm{s}}$ represents vectors of service conditions relevant to the production functions

$\beta$ are estimated parameters on the relevant variables; and

$\mathrm{u}_{2}$ are residuals.

The empirical work presented here addresses policing services in Sheridan County, Wyoming USA. We chose to address policing services because it is a delivery-based service where expenditures on that service may be affected by patterns of the built environment (Lieske et al. 2012; Heikkila 2000). Spatially explicit fiscal evaluation of a delivery-based service can provide insight into the relationship between infrastructure development and public service expenditure. Law enforcement expenditures here are the operating expenditures of the Sheridan County Sheriff's department. Following equation 1, law enforcement expenditures are determined by urban form, the wage and salary component of personal income and unobserved factors. This and the other explanatory variables incorporated in the econometric models are summarized in Table 1. All data are time series covering 22 years from 1990 to 2011. In all cases data represent 22 observations $(n=22)$. Expenditure data for the Sheridan County Sheriff's Department ( $\mathrm{LE}_{\mathrm{EXP}}$ ) are published by the Wyoming Department of Audit (2012) and earlier titles in the same series. A gap in the data required law enforcement expenditures for 1990 to be modeled based on annual percent changes occurring over the remainder of the time period of the analysis (1991-2011). All financial data are inflation adjusted to 2011.

Service conditions used in the estimation of policing services expenditures are both a spatial index of urban form (Res) as well as the wage and salary component of personal income (WageSalary) made available by the United States Bureau of Economic Analysis (2012). The spatial index summarizes clustering and dispersion in the built environment based on the building value for each parcel measured in currency units. The index is calculated as the average of the local Moran's $I$ values for individual areal units where the sum of the building value is greater than zero (Lieske et al. 2012). The spatial index is interpreted similarly to Moran's $I$ where greater values suggest greater clustering and lower values suggest greater dispersion.

The dependent variable of the production function is a public safety index (PSI) measured as the inverse of the crime rate for the unincorporated area of Sheridan County. PSI was calculated from index crime data from the Wyoming Department of Criminal Investigation (2012) and population data from the Wyoming Division of Economic Analysis (2011a, b, c). Operating expenditures of the Sheridan County Sheriff's department ( $\mathrm{LE}_{\mathrm{EXP}}$ ), the population of the municipal areas of Sheridan 
Table 1 Definition of variables

\begin{tabular}{lll}
\hline Variable & Definition & Units \\
\hline LE & Operating Expenditures of the Sheridan County Sheriff's Dept. & \$USD 2011 \\
Res & Spatial index representing residential urban form & Spatial Index \\
WageSalary & The wage and salary component of personal income for & SUSD 2011 \\
& Sheridan County & Years \\
PSI & Time & Index \\
PopMuni & Public Safety Index for the unincorporated portion of Sheridan & \\
Transport & Population of the municipal areas of Sheridan County & Individuals \\
\hline
\end{tabular}

County (PopMuni) and the transportation component of the Wyoming cost of living indices (Transport) (Wyoming Division of Economic Analysis 2013) were also incorporated in the production function. A time variable $(\mathrm{t})$ was included in both the expenditure and production models in order to de-trend the data. The production model augments the expenditure model by clearly presenting the link between inputs (expenditure) and outputs (public safety).

In order to address concerns about the influence of the modifiable areal unit problem (MAUP) expenditure and fiscal efficiency estimations were developed for two analysis layers: 1) a grid with cells one square mile in size and, 2) a grid with cells one square kilometer in size. Data attributes in the analysis layers are local metrics of the built environment calculated using dynamic attributes. Similar to indicators, CommunityViz ${ }^{\circledR}$ enables development of formula-based GIS data attributes referred to as "dynamic attributes" (Walker and Daniels 2011 p. 32). Dynamic attributes were used to develop the sum of building value attribute needed for calculation of the spatial index. Dynamic attributes were also used to make the implications of the econometric model spatially explicit by transferring the results of the econometric model back into the areal units of the analysis grids. As with the calculation of the spatial index, the grid cells used to develop the revenue, expenditure and fiscal efficiency maps are those cells with a residential building value greater than zero.

The first step in developing the revenue model was to calculate property taxes for each residential parcel in the county. A PSS-built dynamic attribute, 'tax district', assigned each parcel the code of the appropriate property tax jurisdiction based on spatial data from the Wyoming Department of Revenue (2013). The dynamic attribute 'mill levy' (a specified tax rate) assigned the correct tax rate to each parcel based on tax district. The dynamic attribute 'residential property tax' brings the mill levy attribute into the same formula used by the county assessor in order to estimate property tax for each parcel. Moving from a parcel layer with dynamic attributes to the analysis grids, dynamic attributes were used for each analysis grid to aggregate residential property taxes for each 1 square mile and 1 square kilometer grid cell. This aggregated property tax value was multiplied by the average percent of property taxes that cover Sheriff's expenditures in the County in order to estimate the overall contribution of property taxes that go to cover policing services expenditure for each grid cell. 
Policing services expenditure was also modelled using a series of dynamic attributes. Similar to the aggregation of property tax from parcel to grid cell, building value data for each residential parcel record were summed for each cell in the analysis grids. Global and local indicators of spatial association (Moran's $I$ ) statistics were calculated (outside the PSS) from the building value sum recorded for each cell. The dynamic attribute 'Morans' then quantified the influence of each cell on the spatial index. In this step a PSS dynamic attribute formula is used to transform the set of local Moran's I statistics, which includes a mix of positively and negatively signed values, into a set of similarly signed numbers that can be used to estimate the spatially defined contribution of each cell to law enforcement expenditures. Next, the dynamic attribute 'regression model' recalculated the expenditure model based on the contribution to clustering for each cell. This is a ceteris paribus evaluation of the change in expenditure for each grid cell in the analysis. The dynamic attribute 'expenditure' then calculates the contribution to clustering of the cell based on the output of the regression. The magnitude of the difference between the original global expenditure value and the modelled cell-based expenditure value indicates the degree to which the urban form of a cell influences expenditures. The result is a spatially explicit assessment of expenditure associated with the different levels of residential clustering and distribution within each cell in the study area.

Finally, the dynamic attribute 'fiscally efficient' used an if/then formula to contrast revenue with expenditure for each cell. Fiscal efficiency (whether a cell contributes more in tax payments than it demands in services) and inefficiency (where the modeled demand for service is greater than revenue) was then mapped in a spatially explicit fashion.

\section{Results}

Results evaluating the effects of infrastructure development on residential growth consist of both exploratory and statistical data analyses. Results were calculated from the time SAWS was fully constructed forward to the most recent date for which data were available at the time the analysis was undertaken, 1996 through 2011. The exploratory data analysis addresses the rates of modeled growth of residential parcels from 1996 to 2011 in the service regions in Sheridan County. The summary of modelled growth rates of residential parcels in Sheridan County is presented in Table 2. Both overall and average annual growth rates show higher growth in the Little Goose watershed and within the SAWS project area in its entirety than the extra-municipal region of the county.

Figure 2 presents a graphical disaggregation of the trends summarized in Table 2. It allows direct visual comparison of data representing the regions of interest (SAWS, the Big Goose watershed, the Little Goose watershed and the urban service area) contrasted with the extra-municipal region of Sheridan County. In addition to data from 1996 to 2011, Fig. 2 also shows data from 1991 to 1995 in order to enable comparison of growth trends before and after full SAWS construction. In Fig. 2 the regions of interest are represented with dark lines in all frames and the contrasting, extra-municipal region is represented with a lighter colored line. Figure 2 (SAWS) shows growth is consistently higher in the SAWS project area than in the extra-municipal area of the county across the time period of the study. The exception is 1992-1993 where growth rates are 
Table 2 Modeled growth in residential parcels in Sheridan County, Wyoming (1996-2011)

\begin{tabular}{lll}
\hline Region & $\begin{array}{l}\text { Overall } \\
\text { Growth Rate (\%) }\end{array}$ & $\begin{array}{l}\text { Average Annual } \\
\text { Growth Rate (\%) }\end{array}$ \\
\hline Little Goose & 49.38 & 3.09 \\
SAWS Project Area & 42.00 & 2.10 \\
Big Goose & 22.00 & 1.38 \\
Urban Service Boundary & 18.35 & 0.92 \\
Extra-Municipal & 14.52 & 0.73 \\
\hline
\end{tabular}

equal. The focus of growth within the SAWS project area is indicated in Fig. 2 (Big Goose) and Fig. 2 (Little Goose). Growth rates in the Big Goose watershed are mostly higher than those in the extra-municipal region of the county. Growth rates in the Little Goose watershed are markedly higher than in the extra-municipal portion of the county throughout most of the time period. Figure 2 (Urban Service) shows residential growth was mostly higher in the urban service area and within municipal boundaries than in the extra-municipal area of the county after installation of the waterline in Big Goose Creek in 1996.

In addition to exploratory data analysis, growth may be evaluated statistically using a linear regression test for trend. Annual growth rates in the extra-municipal region are subtracted from the annual growth rates of the regions of interest. These differenced values are regressed on time which allows evaluation of the null hypothesis that the trend line is equal to zero. Results (Fig. 3) show differenced growth rates and trend lines when comparing the regions of interest with the extra-municipal area. There are statistically significant differences in trend between both SAWS in its entirety and the Little Goose watershed when compared with extra-municipal growth. In all cases residuals are normally distributed with constant variance. There are statistically significant negative signs on the slope values for SAWS and Little Goose Creek. These signs and the corresponding graphical depiction of the downward slope indicate the difference in growth rates is decreasing over time. Trend lines for the Big Goose watershed and the urban service area are not statistically significant. In light of Figs. 3 and 2 (SAWS), Fig. 2 (Big Goose) and Fig. 2 (Little Goose), it is apparent SAWS initially attracted growth but this influence has waned over time. Figure 3 further confirms the results of Table 2 as the former indicates there is neither a statistically significant

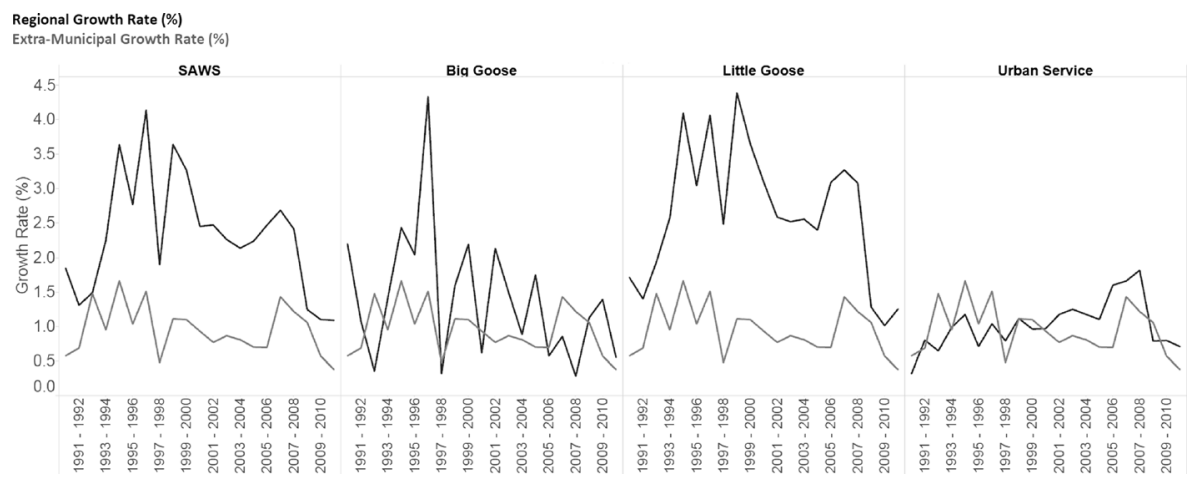

Fig. 2 Growth rates of residential parcels by regions in Sheridan County, Wyoming 

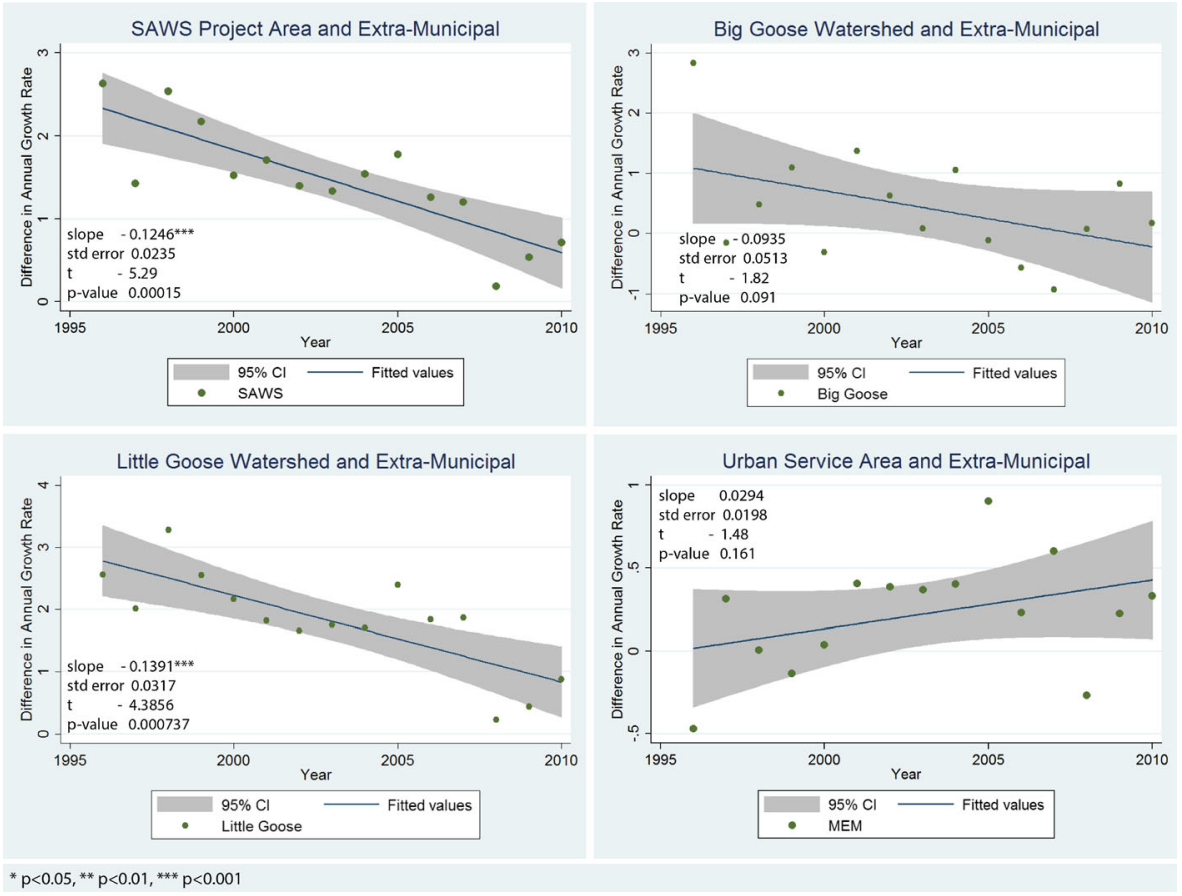

Fig. 3 Differenced growth rates and trend lines

difference in growth between the Big Goose watershed and the extra-municipal area of the County, nor such a difference between the urban service area and the extramunicipal areas of the county. In summary, from the time SAWS was fully constructed forward, residential growth is significantly greater in the SAWS project area as a whole and in the Little Goose Creek watershed than in the extra-municipal area of the county.

Results of the service expenditure econometric model (Table 3) show a statistically significant relationship between urban form and law enforcement expenditures in both the one square mile and one square kilometer analysis grid. In the first regression (one square mile grid) residential development is specified as the inverse of the spatial index. The positive sign indicates that as residential development becomes more dispersed, policing service expenditures increase. Regression two (one square kilometer grid) is specified with standard and the quadratic form of the spatial index (Res and Res ${ }^{2}$ ). The sign on the standard form of the spatial index is negative, indicating that as the built environment becomes more dispersed expenditures on policing services increase. The positive relationship between expenditures and the square of the spatial index demonstrates that as clustering decreases expenditures increase at an increasing rate. The positive sign on the income variable (WageSalary) indicates that policing services expenditure increases commensurately with the wage and salary component of personal income. Comparison of results based on data inputs of multiple resolutions (cell sizes) allows an initial assessment of the influence of the MAUP. The influence of the MAUP is thought to be minimal where results of models of different spatial resolutions are approximately equal. Consistency in these results suggests minimal influence of the MAUP at these scales. 
Table 3 Sheridan county service expenditure regression results

\begin{tabular}{ll}
\hline 1 Sq. Mile & \\
Grid & 1 Sq. km \\
$(1)$ & Grid \\
$\mathrm{b} / \mathrm{se}$ & $(2)$ \\
& $\mathrm{b} / \mathrm{se}$ \\
\hline
\end{tabular}

Expenditure
1/Res
$51829635^{* * *}$

(12574483)

$\begin{array}{lll}\text { Res } & & \begin{array}{l}-2.446 \mathrm{e}+07^{* * *} \\ (4823220)\end{array} \\ \text { Res }^{2} & & 1786926^{* * *} \\ & & (321226) \\ \text { WageSalary } & 4.383^{* * *} & 3.706^{* * *} \\ \mathrm{t} & (1.00) & (0.88) \\ & -3637 & 105830 * \\ \text { constant } & (15202) & (46638) \\ & -1.511 \mathrm{e}+07^{* * *} & 81671517 * * * \\ \text { R-sqr } & (3397421) & (18737308) \\ & 0.9526 & 0.9652\end{array}$

PSI

\begin{tabular}{|c|c|c|c|}
\hline & \multicolumn{3}{|l|}{ PSI } \\
\hline & \multirow[t]{2}{*}{$\mathrm{LE}_{\mathrm{EXP}}$} & $0.00005 * * *$ & $0.00006 * * *$ \\
\hline & & $(0.000001)$ & $(0.000001)$ \\
\hline & \multirow[t]{2}{*}{ PopMuni } & $-0.041^{*}$ & $-0.043^{* *}$ \\
\hline & & $(0.02)$ & $(0.02)$ \\
\hline & \multirow[t]{2}{*}{ Transport } & 1.952 & 1.472 \\
\hline & & $(1.41)$ & $(1.40)$ \\
\hline & \multirow[t]{2}{*}{$\mathrm{t}$} & 6.201 & 5.988 \\
\hline & & $(3.45)$ & $(3.36)$ \\
\hline & \multirow[t]{2}{*}{ constant } & $662.707 * *$ & $691.179 * *$ \\
\hline & & (253.29) & $(248.88)$ \\
\hline $\begin{array}{l}p<0.05, * * p<0.01, * * * \\
<0.001\end{array}$ & R-sqr & 0.7781 & 0.7715 \\
\hline
\end{tabular}

$* p<0.05, * * p<0.01, * * *$ $p<0.001$

The public service production function, illustrating the production of the public safety (PSI) is shown in the lower panel of Table 3. The instruments for law enforcement expenditures and the urban population of Sheridan County are both significant drivers of the level of public safety. The sign on expenditures is positive as expected, meaning higher spending is correlated with greater public safety. The municipal population level in Sheridan County is inversely correlated with public safety. Post-estimation tests show no evidence of serial correlation in the estimations nor was heteroskedasticity detected.

The inverse (one square mile grid) and non-linear (one square kilometer grid) influence of residential urban form on police expenditure found here is congruent with work that posits a U-shaped relationship between urban form and delivery-based public service expenditure. This relationship between public services expenditure and urban form was hypothesized by Studenski (1930) 


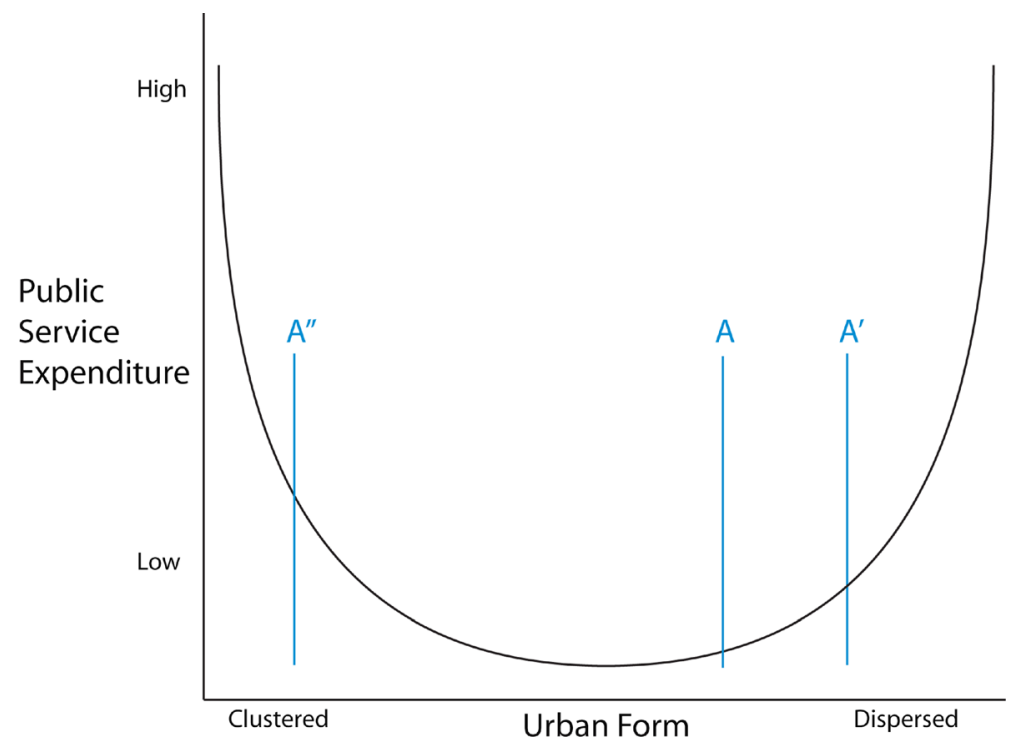

Fig. 4 Urban form expenditure curve

and Colm (1936) and noted more recently by Ladd (1992) and Warner and Pratt (2005). As illustrated in Fig. 4, the urban form expenditure curve, these authors suggest communities like Sheridan County, where development has become more dispersed, will see an increase in expenditure for delivery-based services. In this situation low density developments distant from nodes of service provision are more expensive to service than proximate, high density developments. This change is illustrated in Fig. 4 as the movement between $A$ and A'. However, clustering in the built environment (higher density) may also bring about increases in expenditure where high clustering in the built environment impedes delivery-based services. This is illustrated in Fig. 4 as the change from A to A". Decreases in expenditure may occur when dispersed communities may become more clustered (e.g., Fig. 4 A' to A) or high clustered communities become more dispersed (e.g., Fig. 4 A" toward A). Implicit in Fig. 4 is that for public services where expenditure is in part spatially determined, every land-use decision in a community is a choice between moving left or right on the expenditure curve.

The spatial results of the revenue, expenditure, and fiscal efficiency models of policing services in Sheridan County on the one square kilometer grid are presented in Fig. 5. Mapped results of the revenue model are presented in Fig. 5 (Revenue). Results show the highest revenues are generated within the urban services area. Areas within the SAWS boundary, especially within the Little Goose watershed, generate higher revenues than more outlying areas of the county. Mapped expenditure model results are shown in Fig. 5 (Expenditure). The spatially explicit expenditure model shows the highest expenditures are tightly clustered within the urban service area in what is the City of Sheridan. Highly clustered cells incur greater expenditures than more dispersed cells. Expenditure decreases in outlying areas. The fiscal efficiency map, Fig. 5 (Fiscal Efficiency), shows much of the residential development in the urban service area, the Little Goose watershed 


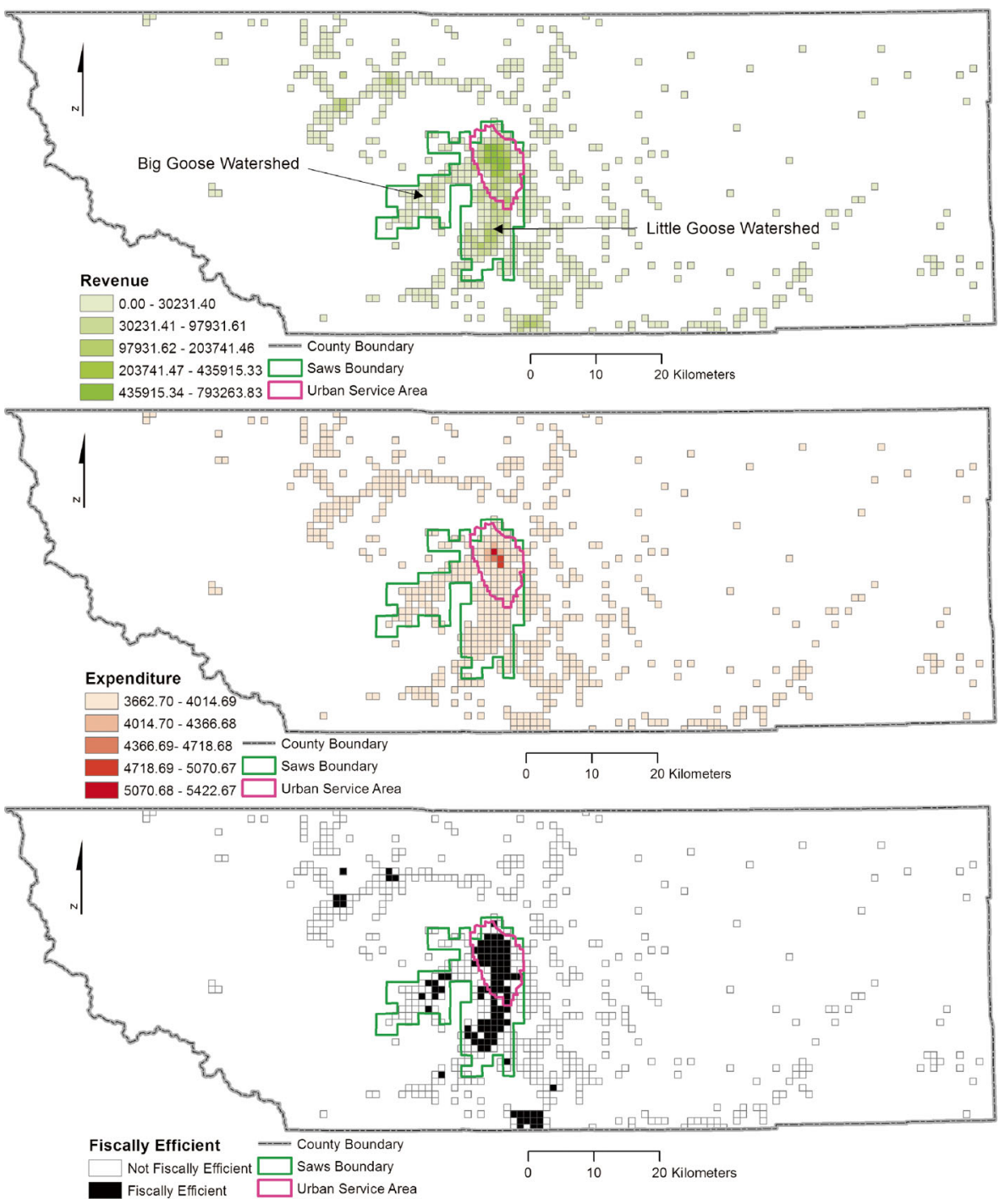

Fig. 5 Revenue, expenditure and fiscal efficiency of policing services in Sheridan County, Wyoming

and some of the residential development in the Big Goose watershed are fiscally efficient for the provision of policing services. These results suggest the increased residential growth clustered to obtain infrastructure benefits is in some cases fiscally efficient for service provision. Mapped results of the one square mile grid (not shown) are nearly identical to the mapped results of the one square kilometer grid shown in Fig. 5.

\section{Discussion and Conclusions}

The goal of this paper is to evaluate and communicate the land-use change, residential growth, and public service expenditure impacts of the Sheridan Area Water Supply 
project. Empirical findings suggest that the construction of the SAWS project has led to increasing residential growth in the SAWS project area, especially within the Little Goose Creek watershed. Residential growth in these areas from 1996 to 2011 was significantly higher than in the extra-municipal area of Sheridan County. This demonstrates SAWS water infrastructure development encouraged residential growth. Statistically significant downward trends in differenced growth in the SAWS project area and the Little Goose Creek watershed, when compared with extra-municipal growth (Fig. 3) indicate an initial jump in residential growth due to infrastructure development and a waning of that growth over time. This suggests that when there is residential growth associated with water infrastructure development, it will take place quickly.

The impact of residential growth in the SAWS project area on public services expenditure is evaluated by combining spatial and econometric modeling to develop spatially explicit models of revenue, expenditures and fiscal efficiency for the provision of policing services in Sheridan County. As expected, areas of highly clustered residential growth within the urban service area are fiscally efficient for the provision of policing services. Much of the residential development associated with SAWS in the Little Goose watershed and some of the residential development associated with SAWS within the Big Goose watershed is also indicated as being fiscally efficient. These results contrast with Cook et al. (2008) who found development outside of urban areas would have identical impacts whether located within SAWS or not. Further, Cook et al. (2008) did not find potential economies of scale for public service provision based on density. The spatially explicit fiscal modeling implemented here found efficiencies in public service provision based on concentrations of residential development within the SAWS project area.

These results also enable evaluation of the efficacy of Sheridan County's planning documents. Consideration of growth trends in the county enables an evaluation of whether the articulated preference for compact development is coming to fruition. Figure 2 (Urban Service) shows extra-municipal growth rates to be mostly higher than growth rates in the urban service area until about the time of the Sheridan 2020 comprehensive planning process. From 2000-2001 forward, with the exception of 2008-2009, growth rates in the urban service area were higher than extra-municipal growth rates. Similarly, the upward slope in differenced growth seen when contrasting the urban service area with the extra-municipal area in Fig. 3 suggests (but does not yet prove) the urban service area designated in the Sheridan County Comprehensive Plan (Clarion et al. 2008) is working to concentrate development. Although not statistically significant, these trends nevertheless suggest Sheridan County is successfully working toward its vision of compact growth in urban areas. Mapped expenditure model results suggest preferences articulated in the Sheridan County Comprehensive Plan (Clarion et al. 2008) and the Sheridan Joint Planning Area Land Use Plan (Clarion 2009) for compact residential growth in order to gain efficiencies in public service provision are, at least in part, being realized.

There are also negative impacts from water development. Residential growth within most of the SAWS project area is not tied to a municipal sewer system. In the SAWS project area residents tap into the water supply line and use septic systems and subsurface runoff (for animal waste or lawn watering) as outflow. Improperly working septic systems can degrade groundwater quality. Occasional blooms in fecal coliform in 
the SAWS project area may be the cumulative effect of continuing residential growth and failing septic systems (Cook et al. 2008). From the Sheridan County planning documents, growth in the county should occur where there are systems in place to accommodate that growth. This was clearly not the case with SAWS where sewer systems were and are needed to accommodate the residential growth brought about by increased water availability.

These disparate impacts highlight the need to approach future water infrastructure planning as part of a comprehensive planning process rather than as a single issue. The negative impacts of SAWS are directly attributable to a lack of coordination between water and land-use planning. In the future, a coordinated, comprehensive approach to water planning may use these results to proceed with certainty that water development will lead to residential growth. While the link between septic and fecal coliform in Sheridan is not yet proven (Cook at el. 2008), consideration of externalities suggests a need to install complementary infrastructure (e.g., water supply and sewerage services) simultaneously. Comprehensive water development planning will allow land-use planners and county commissioners to manage growth so public service expenditures are minimized, water quality and quantity are maintained or improved and other environmental and scenic amenities may be conserved. This sort of coordination may require a concerted effort and /or changes in authority between water development agencies and local land-use planners and decision makers. From Hanak and Brown (2006), “...better linkages would foster better planning, irrespective of the level of growth targeted" (p. 164).

This research also speaks to the contrasting threads of demonstrated utility, but slow implementation, of PSS in planning practice. Utility is demonstrated with the use of PSS to facilitate spatial modeling, develop metrics of the built environment, and with the incorporation of those metrics in scientific analysis. Region specific growth rates and spatially explicit evaluation of the fiscal efficiency of the provision of policing services results in policy relevant and actionable information. The added value in the use of PSS is in the ease of developing and editing formulae that integrate attributes from multiple spatial data layers in a way that is considerably easier than with standard GIS tools.

Underutilization of PSS is usually characterized by restrictions or bottlenecks involving PSS developers and/or users. The variety of stakeholders associated with SAWS project over the long course of its history (WWDC, Sheridan County, the City of Sheridan, SAWS project area residents, citizens of Sheridan County and citizens of the City of Sheridan) suggests a more nuanced view of PSS stakeholders than the typical dichotomy between developers and users. A useful distinction may be made between PSS users, meaning technology operators, and PSS end users, those who potentially benefit from PSS products. End users will ideally benefit from PSS through improved and / or additional information and may also enjoy improved planning outcomes. With this distinction in mind, a comprehensive list of PSS stakeholders may include developers, users (technology operators), and end users. This latter group may include government practitioners (e.g., planners), elected officials and citizens. PSS researchers are also stakeholders in this arena. These categories are not exclusive. There may of course be cases where developers are also PSS users, government practitioners are PSS users and PSS researchers are end users, citizens who may benefit from improved planning in a community. 
Bottlenecks to PSS implementation found in the literature include lack of awareness of potential applications (Geertman and Stillwell 2009, Vonk et al. 2005). Te Brömmelstroet (2012) lists a number of other bottlenecks that suggest PSS are not capable of addressing problems at hand. The detailed conceptualization of PSS stakeholders presented above, particularly the disaggregation of users, allows refinement of these bottlenecks. On the one hand, PSS users (technology operators) supporting this research did not find the Scenario360 module of CommunityViz to be in any way limited by the technology related bottlenecks put forward by Te Brömmelstroet (2012). On the other hand, there is no apparent adoption of PSS by any of the government end users and the impact of this research remains to be seen. Although the WWDC funded initial work on the impact of SAWS (Cook et al. 2008), there is not yet any indication that the ideas developed here will impact water infrastructure development and land-use planning. The hope is this work serves as a demonstration project or prototyping process that generates awareness of PSS use applied to infrastructure development, land-use change and local government expenditure evaluation. In this way, this investigation supports PSS adoption through promotion of the benefits of demonstration projects (Vonk et al. 2005) that successfully address standard and desirable planning tasks and meets the demands of planners and (Vonk and Geertman 2008).

This work suggests several future research directions. The disaggregation of PSS stakeholders presented above may augment and improve analytical approaches to the evaluation of PSS implementation. It should be possible to identify which PSS stakeholders are affected by specific bottlenecks, and identify whether those bottlenecks are successfully overcome within the scope of a PSS augmented project. Finally, the Sheridan County land-use plan mentions potential efficiencies from compact development in the provision of water, sewer, fire, schools and parks. These services, all of which have a possible spatial component to expenditure, suggest a need for further research evaluating the relationship between urban form and expenditures for additional public services.

Acknowledgments This work was supported by the United States Department of Agriculture National Institute of Food and Agriculture Award Number: 2011-67024-30121.

\section{Compliance with Ethical Standards}

Conflict of Interest The authors declare that they have no conflict of interest.

Human and Animal Rights and Informed Consent This article does not contain any studies with human participants performed by any of the authors.

Open Access This article is distributed under the terms of the Creative Commons Attribution License which permits any use, distribution, and reproduction in any medium, provided the original author(s) and the source are credited.

\section{References}

Anderson, W. P., Kanaroglou, P. S., \& Miller, E. J. (1996). Urban form, energy and the environment: a review of issues, evidence and policy. Urban Studies, 33(1), 7-35. 
Borcherding, T. E., \& Deacon, R. T. (1972). The demand for the services of non-federal governments. The American Economic Review, 62(5), 891-901.

Bureau of Economic Analysis. (2012). Regional data, GDP \& personal income, local area personal income, personal income and earnings by industry. United States department of commerce bureau of economic analysis www.bea.gov/iTable/index_regional_cfm.

Center for Natural Resources and Environmental Policy. (2011). Bridging the Governance Gap: Strategies to Integrate Water and Land Use Planning. Policy Report \#7. University of Montana. Available at http:// cnrep.org/policy-reports.html.

Clarion. (2009). Sheridan Joint Planning Area Land Use Plan. http://www.sheridanwy.net/departments/publicworks/planning.

Clarion, Fehr \& Peers, AVI. (2008). Sheridan County Comprehensive Plan. Sheridan County, Wyoming. http://www.sheridancounty.com/info/pw-plan/complan.php.

Colm, G. (1936). Theory of public expenditures. Annals of the American Academy of Political and Social Science, 183, 1-11.

Cook, D., Coupal, R., Hamerlinck, J., Heerman, J., Hulme, D., Lieske, S. \& McLeod, D. (2008). Impacts of Wyoming Water Development Commission Regional Water System Projects on Land Use: An Analysis of Two Case Studies. Ruckelshaus Institute of Environment and Natural Resources Research Project Final Technical Report. Laramie: University of Wyoming.

Geertman, S. (2013). Planning support: from systems to science. Proceedings of the ICE - Urban Design and Planning, 166, 50-59.

Geertman, S., \& Stillwell, J. (2009). Planning Support Systems: Content, Issues and Trends. In S. Geertman, \& J. Stillwell (Eds.), Planning support systems best practice and new methods (pp. 1-26). Netherlands, Dordrecht: Springer.

Geertman, S., Stillwell, J., \& Toppen, F. (2013). Introduction to "Planning Support Systems for Sustainable Urban Development”. In S. Geertman, F. Toppen, \& J. Stillwell (Eds.), Planning support systems for sustainable urban development (pp. 1-15). Berlin: Springer.

Hamerlinck J.D., Lieske S.N. \& Gribb W.L. (2013). Understanding Wyoming's Land Resources: Land-Use Patterns and Development Trends. Ruckelshaus Institute of Environment and Natural Resources. University of Wyoming-Laramie.

Hanak, E., \& Browne, M. K. (2006). Linking housing growth to water supply: new planning frontiers in the American West. Journal of the American Planning Association, 72, 154-166.

Heikkila, E. (2000). The Economics of Planning. New Brunswick: Center for Urban Policy Research.

Hirsch, W. Z. (1970). The economics of state and local government, Economics handbook series. New York: McGraw-Hill.

Howard Needles Tammen \& Bergendoff. (1987). Executive Summary Sheridan Area Water Supply Investigation Level II Phase 21986 Program. Water Resources Data System Library http://library.wrds.uwyo.edu/wwdcrept/.

Klosterman, R. E. (1997). Planning support systems: a new perspective on computer-aided planning. Journal of Planning Education and Research, 17(1), 45-54.

JGA Architects-Engineers-Planners and HKM Engineering, Inc. (2001). Vision 2020: Sheridan County Growth Management Plan. Sheridan, Wyoming: City of Sheridan.

Ladd, H. F. (1992). Population growth, density, and the costs of providing public services. Urban Studies, 29(2), 273-295.

Lieske, S. N., \& Gribb, W. J. (2012). Modeling high-resolution spatiotemporal land-use data. Applied Geography, 35, 283-291.

Lieske, S. N., \& Hamerlinck, J. D. (2013). Planning support systems applications in site planning. Proceedings of the ICE - Urban Design and Planning, 166, 34-42.

Lieske, S. N., McLeod, D. M., Coupal, R. H., \& Srivastava, S. K. (2012). Determining the relationship between urban form and the costs of public services. Environment and Planning B, 39(1), 155-173.

Lieske, S. N., Coupal, R. H., Hamerlinck, J. D., McLeod, D. M., \& Scofield, A. M. (2013). Planning support systems for fiscally sustainable planning. In S. Geertman, F. Toppen, \& J. Stillwell (Eds.), Planning support systems for sustainable urban development (pp. 127-147). Berlin: Springer.

Nedović-Budić, Z. (2000). Geographic information science implications for urban and regional planning. Journal of the Urban and Regional Information Systems Association, 12(2), 81-93.

Studenski, P. (1930). The government of metropolitan areas in the United States. National Municipal League New York. Government.

te Brömmelstroet, M. (2012). Transparency, flexibility, simplicity: From buzzwords to strategies for real PSS improvement. Computers, Environment and Urban Systems, 36, 96-104.

te Brömmelstroet, M. (2013). Performance of planning support systems: what is it, and how do we report on it? Computers, Environment and Urban Systems, 41, 299-308. 
Vonk, G., \& Geertman, S. (2008). Improving the adoption and use of planning support systems in practice. Applied Spatial Analysis and Policy, 1, 153-173.

Vonk, G., Geertman, S., \& Schot, P. (2005). Bottlenecks blocking widespread usage of planning support systems. Environment and Planning A, 37, 909-924.

Walker, D., \& Daniels, T. L. (2011). The planners guide to CommunityViz: the essential tool for a new generation of planning. Chicago: Planners Press, American Planning Association.

Warner, M. E., \& Pratt, J. E. (2005). Spatial diversity in local government revenue effort under decentralization: a neural-network approach. Environment and Planning C: Government and Policy, 23, 657-677.

Wyoming Department of Audit. (2012). Cost of Maintaining County Government http://audit.state.wy.us/ PFUNDS/reports_to_legislature.asp.

Wyoming Department of Criminal Investigation. (2012). Wyoming Department of Criminal Investigation Annual Crime Reports 1999-2010 attorneygeneral.state.wy.us/dci/CrimeInWyomingReports.html.

Wyoming Department of Revenue. (2013). Wyoming Department of Revenue Property Tax Division, Computer Assisted Mass Appraisal (CAMA). http://cama.state.wy.us/CAMADATA/ TBLDATADOWNLOAD/AddTBLDATADOWNLOAD.aspx.

Wyoming Division of Economic Analysis. (2011a). Wyoming Incorporated Place Population Estimates: April 1, 2010 to July 1, 2012. http://eadiv.state.wy.us/pop/SUB-12EST.htm.

Wyoming Division of Economic Analysis. (2011b). Intercensal Estimates of the Resident Population for Counties of Wyoming: April 1, 2000 to July 1, 2010 http://eadiv.state.wy.us/pop/sub-est01-09.htm.

Wyoming Division of Economic Analysis. (2011c). Population for Wyoming, Counties, Cities, and Towns: 1990 to 2000. http://eadiv.state.wy.us/pop/c\&sc90_00.htm.

Wyoming Division of Economic Analysis. (2013). Wyoming Cost of Living for the Fourth Quarter 2012. http://eadiv.state.wy.us/wcli/wcli.html. 